Dhaka Univ. J. Biol. Sci. 29(2): 155-163, 2020 (July)

\title{
SOIL FERTILITY AND LEAF NUTRIENT STATUS OF MANGO ORCHARD SITES
}

\author{
SK. Musfiq-Us-Salehin, Gazi Md. Mohsin ${ }^{1}$, Tabassum Ferdous², \\ Jobaed Ragib Zaman, Md. Jashim UdDin* AND Md. Khalilur Rahman \\ Department of Soil, Water and Environment, University of Dhaka, \\ Dhaka-1000, Bangladesh
}

Key words: Fertility potential, Leaf nutrition, Mango orchards

\begin{abstract}
Twenty soil and leaf samples from 20 orchards of mango (Mangifera indica L.) were collected from different locations of Rajshahi and Satkhira regions to evaluate soil texture, $\mathrm{pH}$, organic matter, available and total nitrogen, phosphorus, potassium and sulfur of soils and the concentration of $\mathrm{N}$ and $\mathrm{K}$ in mango leaves. The $\mathrm{pH}$ of the soil varied from 6.3 - 7.9 and organic matter content varied from 0.72 - 3.60 per cent. The available nitrogen, phosphorus, potassium, and sulfur of the soils ranged from 190 - 510, 39 - 196, 36 - 206 and 25 - 235 $\mathrm{mg} / \mathrm{kg}$, respectively. The values of total $\mathrm{N}, \mathrm{P}, \mathrm{K}$ and $\mathrm{S}$ were $0.03-0.12,0.022$ $0.210,0.235-0.0 .936$ and $0.005-0.266$ per cent, respectively. The dominant soil textural class was silty clay loam. The mean concentration of nitrogen $(0.88 \%)$ and potassium $(0.61 \%)$ in the leaf sample was low. The overall fertility status of the soils of Rajshahi and Satkhira regions in relation to mango cultivation is moderate.
\end{abstract}

\section{Introduction}

Mango (Mangifera indica L.) has become a major fruit crop of the tropics and subtropics, particularly in Asia, the most important fruit crop and where it has always been considered the king of fruits ${ }^{(1)}$. In Bangladesh, its cultivation occupies an area of 37,830 hectares of land with an annual production of 116,1685 metric ton ${ }^{(2)}$. Mango grows in almost all over Bangladesh but commercial and good quality mangoes grow in the northwestern districts of the country. The leading mango growing districts of the country are Rajshahi, Chapainawabgonj and greater Dinajpur. Mango is seasonal cash crop of northwestern region of Bangladesh. Mango exportation from Bangladesh is increasing day by day. In a study conducted( ${ }^{(3)}$ showed that present status of mango cultivation area increased converting the agricultural lands.

*Author for correspondence: <mjuddin66@yahoo.com>. ${ }^{1}$ Department of Agriculture, Noakhali Science and Technology University, Sonapur, Noakhali-3814, Bangladesh. ${ }^{2}$ Soil Resource Development Institute, Ministry of Agriculture, Dhaka-1215, Bangladesh. 
The productivity of mango is hampered due to imbalanced use of fertilizers and

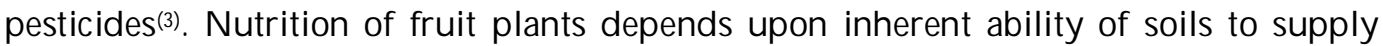
nutrient elements. The key to mineral nutrition of the plants is the judicious use of fertilizers based on soil testing. Plant analysis is also used to confirm the suspected deficiencies and toxicities of nutrients and also to assess the efficacy of fertilizer doses ${ }^{(4)}$. Therefore, it is very important to focus on the soil nutrients availability and other properties pertaining to nutrients if mango production is to be increased. Total nitrogen, phosphorus, potassium and sulfur content in soils and their availability to the plants are vital properties of soil fertility. Soil nutrient of mango is an important part of orchard management practices ${ }^{(5)}$. Essential nutrients have specific role in the plant and their presence is must for the plant to complete its life cycle. Information on mineral nutrient status helps in diagnosis of nutritional problems and estimation of the fertilizer needs of the fruit trees ${ }^{(4)}$. To ascertain these, both soil and plant analyses are necessary as these are complementary to each other and one supplies the information that the other may not. The information on nutritional status of both soil and plant helps to understand about adequate fertilization of the orchards. Practically, no systematic work has been done on the nutritional status of mango orchards in Rajshahi and Satkhira regions of Bangladesh. A few reports are available in relation to the characteristics of mango orchard soils of Bangladesh $^{(6,7)}$. The results obtained here may help in formulation of future nutritional status and in working out accurate fertilizer recommendations in the above mentioned regions.

The present experiment was undertaken to evaluate some physico-chemical properties of mango growing soils of Rajshahi and Satkhira regions and the concentration of nitrogen and potassium in the leaves of mango plants.

\section{Materials and Methods}

The fertility potential of some mango orchard soils as well as nitrogen and potassium content in leaf samples of different sites viz. Charghat, Dargapur, Mohanpur, Godagari, Tanore, Bagmara, Puthia, Paba, Bagha and Rajshahi Sadar Upazila of Rajshahi district and Kolaroa, Tala, Debhata, Assasuni, Satkhira Sadar Upazila of Satkhira district were evaluated. Twenty soil samples (0 - $15 \mathrm{~cm}$ depth) were collected from Rajshahi and Satkhira districts/regions. Soil sampling sites were Charghat, Daragpur, Rajshahi Sadar, Mohanpur, Godagari, Tanore, Bagmara, Puthia, Paba and Bagha Upazilas of Rajshahi district and Municipality, Fingri (Satkhira Upazila), Patkelghata, Sorulia (Tala Upazila), Joynagar, Gopinathpur (Kolaroa Upazila), Parulia, Kulia (Debhata Upazila) and Budhhata, Kulla (Assasuni Upazila) of Satkhira district. Soil samples were air-dried, visible roots and debris were discarded, massive aggregates were broken by using a wooden hammer, ground and sieved using $2 \mathrm{~mm}$ sieve. Samples were kept in

polyethylene bags with proper labeling. Twenty leaf samples (terminal, green colour) 
were collected from the above gardens, wiped with soft white clothes with distilled water, air-dried, oven-dried and powdered in a mechanical grinder and kept in polyethylene bags for laboratory analysis.

The particle size analysis of the soils was determined by hydrometer method ${ }^{(8)}$ and textural class was determined by Marshall's triangle coordinate curve. The $\mathrm{pH}$ of the soil samples (soil and distilled water ratio $1: 2.5$ ) was measured by using a corning glass electrode $\mathrm{pH}$ meter. The organic matter content of soils was determined by wet oxidation method(9). Available nitrogen was determined by extracting the soils with $1 \mathrm{~N} \mathrm{KCl}$ following the micro-Kjeldahl distillation method ${ }^{(10)}$. Available phosphorus extracted by $0.5 \mathrm{M} \mathrm{NaHCO} 3$ was determined colorimetrically by spectrophotometric after developing blue colour using ascorbic acid and potassium antimony tartrate as colour developing reagents (11) available $\mathrm{K}$ was extracted by $1 \mathrm{~N} \mathrm{NH}_{4} \mathrm{OAc}$ and was determined by flame photometer and available sulphur was determined colorimetrically by using spectrophotometer after developing turbidity with $\mathrm{BaCl}_{2}$ using Tween- 80 as the suspending agent of the sulphate precipitation ${ }^{(12)}$. Total nitrogen in the soil samples was determined by micro-Kjeldhal steam distillation method after $\mathrm{H}_{2} \mathrm{SO}_{4}$ acid digestion ${ }^{(10)}$. Soil samples were digested with a mixture of concentrated $\mathrm{HCl} / \mathrm{HNO}_{3}(1: 3)^{(13)}$ for the determination of total $\mathrm{P}, \mathrm{K}$ and $\mathrm{S}$. Total phosphorus was determined by spectrophotometer using Vanadomolybdate yellow color $\operatorname{method}^{(14)}$, total potassium was measured by a flame photometer and total sulphur was determined by spectrophotometer after developing turbidity with $\mathrm{BaCl}_{2}{ }^{(12)}$.

For total $\mathrm{N}$ and $\mathrm{K}$ analysis, $0.1 \mathrm{~g}$ ground leaf sample was digested on sand bath with $5 \mathrm{ml}$ concentrated $\mathrm{H}_{2} \mathrm{SO}_{4}$ and $2 \mathrm{ml} 4 \%(\mathrm{v} /)$ solution of perchloric acid (62\%) in concentrated $\mathrm{H}_{2} \mathrm{SO}_{4}$. The digest was cooled and diluted to $100 \mathrm{ml}$ with deionized water ${ }^{(15)}$. The concentration of $\mathrm{N}$ in leaf was determined by micro-Kjeldhal steam distillation method. The concentration of potassium in leaf was determined by a flame photometer.

\section{Results and Discussion}

Texture in the soils of Rajshahi district ranged from loam to silt loam and in Satkhira district, it varied from silty clay loam to silt loam (Table 1). The soils were coarser in nature having silty clay loam as the predominant texture in both Rajshahi and Satkhira regions (Table 1). The sand/silt ratio in the soils of Rajshahi ranged from $0.08-1.21$ and the average silt/clay ratio varied from $1.47-3.26$. The sand/silt ratio varied from 0.12 to 0.35 and silt/clay ratio ranged from 1.94 - 3.16 in the soils of Satkhira. It was reported that well drained sandy loam to loam soils provide the best environment for mango production ${ }^{(16)}$. 
Table 1. Particle size distribution of some selected soils of mango orchard sites of Rajshahi and Satkhira regions.

\begin{tabular}{|c|c|c|c|c|c|c|c|}
\hline & Locations & $\%$ sand & $\%$ silt & $\%$ clay & $\begin{array}{c}\text { Textural } \\
\text { class }\end{array}$ & $\begin{array}{c}\text { Sand/silt } \\
\text { ratio }\end{array}$ & $\begin{array}{c}\text { Silt/clay } \\
\text { ratio }\end{array}$ \\
\hline \multirow{9}{*}{ 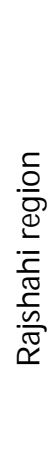 } & Charghat & 44 & 42 & 14 & 1 & 1.05 & 3.0 \\
\hline & Daragpur & 14 & 52 & 34 & scl & 0.27 & 1.53 \\
\hline & RajshahiSadar & 6 & 70 & 24 & scl & 0.08 & 2.92 \\
\hline & Mohanpur & 24 & 50 & 34 & sl & 0.48 & 1.47 \\
\hline & Godagari & 16 & 50 & 34 & scl & 0.32 & 1.47 \\
\hline & Tanore & 24 & 50 & 26 & scl & 0.48 & 1.92 \\
\hline & Bagmara & 31 & 48 & 21 & 1 & 0.64 & 2.29 \\
\hline & Puthia & 46 & 38 & 16 & 1 & 1.21 & 2.38 \\
\hline & Paba & 19 & 62 & 19 & sl & 0.31 & 3.26 \\
\hline \multirow{11}{*}{ 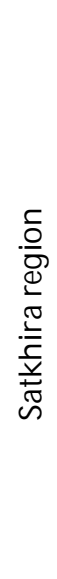 } & Bagha & 19 & 60 & 21 & sl & 0.32 & 2.86 \\
\hline & Municipality & 19 & 50 & 31 & scl & 0.38 & 1.61 \\
\hline & Fingri & 9 & 67 & 24 & scl & 0.13 & 2.79 \\
\hline & Patkelghata & 9 & 60 & 31 & scl & 0.15 & 1.94 \\
\hline & Sorulia & 10 & 60 & 26 & scl & 0.17 & 2.31 \\
\hline & Jaynagar & 14 & 60 & 26 & scl & 0.23 & 2.31 \\
\hline & Gopinathpur & 14 & 65 & 21 & sl & 0.22 & 3.10 \\
\hline & Parulia & 19 & 60 & 21 & sl & 0.32 & 2.86 \\
\hline & Kulia & 21 & 60 & 19 & sl & 0.35 & 3.16 \\
\hline & Budhhata & 8 & 66 & 26 & scl & 0.12 & 2.54 \\
\hline & Kulla & 16 & 63 & 21 & sl & 0.25 & 3.0 \\
\hline
\end{tabular}

1 : Loam, scl : Silty clay loam, sl : Silt loam.

The $\mathrm{pH}$ of soil samples of Rajshahi region varied from 6.3 to 7.9 having a mean value of 7.31 which indicate neutral soil reaction. Soils of Tanore and Bagmara showed $\mathrm{pH}$ of less than 7.0, all other Upazilas showed $\mathrm{pH}$ of greater than 7.0 (Table 2). Soils from Satkhira district showed $\mathrm{pH}$ of 6.4 - 7.5. Optimum $\mathrm{pH}$ varies from 5.5 - 7.8 for mango cultivation ${ }^{(16)}$. Organic matter ranged from 1.08 to $3.60 \%$ in Rajshahi and 0.72 to $3.24 \%$ in Satkhira region. According to the soil organic matter categorization as reported ${ }^{(17)}$, the soil organic matter contents of surface soils were in the range of 1.08 to $3.60 \%$ was categorized as medium in the Rajshahi region and the organic matter contents between 0.72 and $3.24 \%$ in the Satkhira region categorized as medium. The available $\mathrm{N}$ in the soils of Rajshahi region ranged from $180-410 \mathrm{mg} / \mathrm{kg}$ with a mean of $294 \mathrm{mg} / \mathrm{kg}$. In Satkhira region, available $\mathrm{N}$ ranged from $190-540 \mathrm{mg} / \mathrm{kg}$ with a mean of $340.5 \mathrm{mg} / \mathrm{kg}$. Similar 
observation on available nitrogen was reported in sandy loam soils of mango orchard field ${ }^{(4)}$. The total nitrogen content in the soils of Rajshahi region ranged from 0.03 to $0.12 \%$. In Satkhira region, total nitrogen content ranged from 0.05 to $0.12 \%$ (Table 2). According to a study(17), the nitrogen content of the soil sample falls in low category probably due to nitrogen losses through leaching, surface runoff, denitrification, and ammonia volatilization etc. ${ }^{(18)}$. Similar nitrogen content in the mango orchard soils of Rangamati, Khagrachari and Bandarban Hill tracts were reported ${ }^{(7)}$.

Table 2. Chemical properties of some selected soils of mango orchard sites of Rajshahi and Satkhira regions.

\begin{tabular}{|c|c|c|c|c|c|c|c|c|c|c|c|}
\hline & \multirow[b]{2}{*}{ Locations } & \multirow[b]{2}{*}{$\mathrm{pH}$} & \multirow{2}{*}{$\begin{array}{l}\text { Organic } \\
\text { matter } \\
(\%)\end{array}$} & \multicolumn{2}{|c|}{ Nitrogen } & \multicolumn{2}{|c|}{ Phosphorus } & \multicolumn{2}{|c|}{ Potassium } & \multicolumn{2}{|c|}{ Sulfur } \\
\hline & & & & $\begin{array}{l}\text { Avail- } \\
\text { able } \\
(\mathrm{mg} /)\end{array}$ & $\begin{array}{l}\text { Total } \\
(\%)\end{array}$ & $\begin{array}{c}\text { Avail- } \\
\text { able } \\
(\mathrm{mg} / \mathrm{kg})\end{array}$ & $\begin{array}{c}\text { Total } \\
(\%)\end{array}$ & $\begin{array}{l}\text { Avai- } \\
\text { lable } \\
(\mathrm{mg} / \mathrm{k})\end{array}$ & $\begin{array}{c}\text { Total } \\
(\%)\end{array}$ & $\begin{array}{l}\text { Avail- } \\
\text { able } \\
(\mathrm{mg} / \mathrm{k})\end{array}$ & $\begin{array}{c}\text { Total } \\
(\%)\end{array}$ \\
\hline \multirow{8}{*}{ 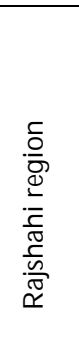 } & Charghat & 7.6 & 1.44 & 300 & 0.07 & 79 & 0.042 & 36 & 0.349 & 34 & 0.009 \\
\hline & Daragpur & 7.9 & 1.08 & 290 & 0.05 & 39 & 0.038 & 85 & 0.376 & 95 & 0.034 \\
\hline & Sadar & 7.7 & 2.76 & 200 & 0.10 & 86 & 0.084 & 100 & 0.513 & 80 & 0.019 \\
\hline & Mohanpur & 7.0 & 1.80 & 280 & 0.06 & 97 & 0.210 & 103 & 0.714 & 102 & 0.187 \\
\hline & Godagari & 7.3 & 3.60 & 300 & 0.12 & 46 & 0.044 & 172 & 0.834 & 120 & 0.083 \\
\hline & Tanore & 6.3 & 2.28 & 390 & 0.08 & 63 & 0.087 & 206 & 0.493 & 170 & 0.138 \\
\hline & Bagmara & 6.7 & 1.56 & 180 & 0.03 & 39 & 0.114 & 68 & 0.463 & 85 & 0.024 \\
\hline & Puthia & 7.2 & 1.90 & 190 & 0.03 & 60 & 0.118 & 62 & 0.533 & 95 & 0.165 \\
\hline \multirow{12}{*}{ 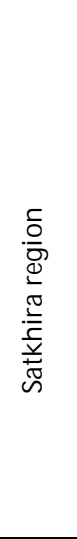 } & Paba & 7.5 & 2.52 & 410 & 0.07 & 60 & 0.136 & 77 & 0.463 & 75 & 0.022 \\
\hline & Bagha & 7.7 & 2.28 & 400 & 0.06 & 67 & 0.177 & 97 & 0.936 & 137 & 0.266 \\
\hline & Municipality & 6.4 & 0.72 & 310 & 0.12 & 196 & 0.117 & 163 & 0.355 & 55 & 0.027 \\
\hline & Fingri & 6.7 & 2.40 & 190 & 0.10 & 60 & 0.033 & 45 & 0.331 & 45 & 0.017 \\
\hline & Patketghata & 7.4 & 2.52 & 290 & 0.10 & 70 & 0.086 & 114 & 0.714 & 176 & 0.111 \\
\hline & Sorulia & 7.2 & 3.24 & 320 & 0.11 & 109 & 0.144 & 201 & 0.694 & 185 & 0.167 \\
\hline & Joynagar & 7.2 & 3.72 & 380 & 0.10 & 99 & 0.089 & 163 & 0.376 & 75 & 0.028 \\
\hline & Gopinathpur & 7.4 & 2.04 & 510 & 0.07 & 117 & 0.121 & 131 & 0.343 & 90 & 0.014 \\
\hline & Parulia & 6.8 & 2.28 & 305 & 0.07 & 109 & 0.133 & 77 & 0.269 & 203 & 0.095 \\
\hline & Kulia & 6.7 & 3.00 & 400 & 0.06 & 98 & 0.135 & 71 & 0.563 & 235 & 0.167 \\
\hline & Budhhata & 7.5 & 3.00 & 410 & 0.08 & 90 & 0.022 & 45 & 0.235 & 65 & 0.029 \\
\hline & Kulla & 7.3 & 2.04 & 290 & 0.05 & 107 & 0.023 & 39 & 0.269 & 25 & 0.005 \\
\hline Mean & & 7.2 & 2.31 & 317.3 & 0.076 & 81.55 & 0.085 & 102.75 & 0.424 & 107.35 & 0.065 \\
\hline
\end{tabular}

The available $\mathrm{P}$ in the soils of Rajshahi region ranged from 39 to $97 \mathrm{mg} / \mathrm{kg}$ with an average of $63.6 \mathrm{mg} / \mathrm{kg}$. In Satkhira region, available P ranged from 60 to $196 \mathrm{mg} / \mathrm{kg}$ with an average of $105.5 \mathrm{mg} / \mathrm{kg}$. The mean value for available $\mathrm{P}$ in the study site was 109 $\mathrm{mg} / \mathrm{kg}$. The total phosphorous content in the soils of Rajshahi region ranged from 0.038 to $0.21 \%$ with an average of $0.105 \%$. In Satkhira region, total phosphorus content ranged from 0.022 to $0.144 \%$. The phosphorous content of soil samples was low. The available $\mathrm{K}$ in the soils of Rajshahi region ranged from 36 to $206 \mathrm{mg} / \mathrm{kg}$ with an average of 100.6 
$\mathrm{mg} / \mathrm{kg}$. In Satkhira region, available K ranged from 39 to 201 with an average of 104.9 $\mathrm{mg} / \mathrm{kg}$. The overall available $\mathrm{K}$ in Rajshahi and Satkhira regions were $102.75 \mathrm{mg} / \mathrm{kg}$. The total potassium content in the soil samples was high. The total potassium content of Rajshahi region ranged from $0.349-0.93 \%$ whereas in Satkhira region it ranged from 0.23 - $0.714 \%$ (Table 2). The available sulfur content was $34-170 \mathrm{mg} / \mathrm{kg}$ in Rajshahi region and $25-235 \mathrm{mg} / \mathrm{kg}$ in Satkhira region, respectively. The average value of available $\mathrm{S}$ was 99.3 $\mathrm{mg} / \mathrm{kg}$ in Rajshahi region and $115.4 \mathrm{mg} / \mathrm{kg}$ in Satkhira region. The total sulfur content in the soils of Rajshahi region ranged from $0.009-0.266 \%$ with an average of $0.111 \%$ whereas in Satkhira region, it ranged from 0.005 to $0.167 \%$ with an average of $0.064 \%$.

The analysis of the leaf sample showed that the total nitrogen content of Rajshahi region ranged from $0.86-1.42 \%$ with an average of $1.116 \%$ and in Satkhira region, it ranged from $0.83-1.42 \%$ with an average of $1.340 \%$ (Table 3 ). The potassium content of the leaf samples ranged from $0.37-0.88 \%$ in Rajshahi region with an average of $0.65 \%$. In

Table 3. The concentration of $\mathrm{N}$ and $\mathrm{K}$ in mango leaves of Rajshahi and Satkhira regions.

\begin{tabular}{clcc}
\hline Location & & Nitrogen $(\%)$ & Potassium $(\%)$ \\
\hline Rajshahi & Charghat & $1.42 \pm 0.10$ & $0.78 \pm 0.26$ \\
& Daragpur & $1.03 \pm 0.11$ & $0.46 \pm 0.15$ \\
& Sadar & $1.29 \pm 0.14$ & $0.81 \pm 0.23$ \\
& Mohanpur & $0.90 \pm 0.44$ & $0.37 \pm 0.18$ \\
& Godagari & $1.02 \pm 0.173$ & $0.88 \pm 0.23$ \\
& Tanore & $0.88 \pm 0.41$ & $0.61 \pm 0.19$ \\
& Bagmara & $0.86 \pm 0.41$ & $0.49 \pm 0.16$ \\
& Puthia & $1.16 \pm 0.14$ & $0.56 \pm 0.18$ \\
& Paba & $1.17 \pm 0.12$ & $0.86 \pm 0.28$ \\
& Bagha & $1.43 \pm 0.10$ & $0.67 \pm 0.22$ \\
Satkhira & Municipality & $1.18 \pm 0.17$ & $0.80 \pm 0.26$ \\
& Fingri & $1.01 \pm 0.28$ & $0.65 \pm 0.20$ \\
& Patkelghata & $0.91 \pm 0.41$ & $0.68 \pm 0.22$ \\
& Sorulia & $1.15 \pm 0.13$ & $0.55 \pm 0.16$ \\
& Joynagar & $1.41 \pm 0.13$ & $0.91 \pm 0.30$ \\
& Gopinathpur & $0.83 \pm 0.16$ & $0.66 \pm 0.22$ \\
& Parulia & $1.19 \pm 0.12$ & $0.79 \pm 0.21$ \\
& Kulia & $1.04 \pm 0.12$ & $0.76 \pm 0.25$ \\
& Budhhata & $1.20 \pm 0.11$ & $0.62 \pm 0.20$ \\
& Kulla & $1.42 \pm 0.17$ & $0.38 \pm 0.12$ \\
\hline Mean & & 0.88 & 0.61 \\
\hline & & &
\end{tabular}


case of Satkhira region the range was from $0.38-0.91 \%$ with an average of $0.68 \%$. The overall concentration of $\mathrm{N}$ and $\mathrm{K}$ in the leaf sample was 0.88 and $0.61 \%$ in Rajshahi and Satkhira regions, respectively. The concentration of $\mathrm{N}$ and $\mathrm{K}$ was low in the leaf samples of Rajshahi and Satkhira regions. It was reported in a study that the leaves of mango plants of Rajshahi and Dhaka contained $0.63-1.85 \%$ nitrogen, $0.16-0.20 \%$ phosphorus, $0.51-0.89 \%$ potassium ${ }^{(6)}$. The percentage of $\mathrm{N}$ in mango leaf blades and petioles at different dates were 1.50 to 2.17 and 1.013 to 1.707 , respectively ${ }^{(19)}$. A field experiment ${ }^{(20)}$ was conducted to examine the effects of $K$ fertilization on leaf $K$, nutrient yield and quality in pistachio (Pistacia vera L.). Pistachio trees exhibited highly fluctuating seasonal leaf $\mathrm{K}$ levels. Leaf $\mathrm{K}$ concentration was low $(<10 \mathrm{~g} / \mathrm{kg})$ during spring flush, increased dramatically during fruit development and declined rapidly after harvest.

Queensland Department of Agriculture and Fisheries proposed an outline on optimum nutrient level in leaf of mango(21) (Table 4). The analyzed values were compared with this optimum soil e.g. soil $\mathrm{pH}$, organic carbon, nitrogen, phosphorus, potassium, sulfur etc. and leaf level e.g. percent $\mathrm{N}$ and percent $\mathrm{K}$, for mango fruits which indicates that the soils of Rajshahi and Satkhira regions are at moderate level to support mango production.

Table 4. Comparison of analyzed nutrient levels with optimum levels of soil and leaf samples of Rajshahi and Satkhira regions.

\begin{tabular}{llc}
\hline Elements & *For optimum soil levels & Analyzed nutrient levels \\
\hline $\mathrm{pH}$ & $5.5-7.0$ & $6.3-7.9$ \\
Organic carbon $(\%)$ & $1-3$ & $0.72-3.72$ \\
Nitrogen $(\mathrm{mg} / \mathrm{kg})$ & $<10$ & $180-510$ \\
Phosphorus $(\mathrm{mg} / \mathrm{kg})$ & $60-80$ & $39-196$ \\
Potassium $(\mathrm{meq} / 100 \mathrm{gm})$ & $0.25-0.4$ & $0.10-0.52$ \\
Sulfur $(\mathrm{mg} / \mathrm{kg})$ & $>12$ & $25-203$ \\
& $*$ Optimum leaf levels & \\
$\mathrm{N}(\%)$ & $1-1.5$ & $0.83-1.43$ \\
$\mathrm{~K}(\%)$ & $0.75-1.2$ & $0.37-0.91$ \\
\hline
\end{tabular}

*Source: QDAF, 2015 21$)$

\section{References}

1. Litz RE 2009. The Mango: Botany, Production and Uses. 2nd edition, Wallingford, UK., Cambridge, MA: CABI publication, 2009.

2. BBS 2016. Year book of agricultural statistics of Bangladesh. Bangladesh Bureau of Statistics Division. Ministry of Planning. Govt. of the People's Republic of Bangladesh. pp. 202-203. 
3. Sultana A, MF Chowdhury and AKMK Pervez 2018. Present status of mango cultivation in Bangladesh: Case of Shibganj Upazila of Chaipainawabganj district. J. Agricultural and Rural Res. 2(3): 47-55.

4. Sharma S,M Kaurand ML Verma 2018. Soil fertility and leaf nutrient status of macro-nutrients in mango orchards under Kangra district of Himachal Pradesh. International J. Chemical Studies 6(3): 1317-1322.

5. Ravishankar H, K Kumar, A Singha and T Adak 2010. Integrated nutrient management in mango and guava. Indian J. Horticulture 47: 180-185.

6. Rahman M, F Ahmed and A Islam 1982. Mineral contents of some mango trees of Rajshahi and Dhaka. Bangladesh Hort. 10(2): 35-38.

7. Kibria MG, MJ Ahmad and KT Osman 2011. Soil fertility status of some mango orchards in Chittagong Hill Tracts. Chittagong Univ. J. Biol. Sci. 6(1-2): 187-197.

8. Gee GW and JW Bauder 1986. In: Klute A (ed.), Methods of Soil Analysis. Part 1: Physical and mineralogical methods. pp. 383-409. 2nd ed. Am. Soc. Agron. No. 9.

9. Walkley A and IA Black 1934. An examination of Degtjareff method for determining soil organic matter and a proposed modification of the chromic acid titration method. Soil Sci. 37: 29-38.

10. Marr IL and MS Cresser 1983. The Lithosphere. In: Environmental Chemical Analysis. Blackie and Sons. UK. pp. 155-182.

11. Olsen SR, CV Cole, FS Watanabe and LA Dean 1954. Estimation of available phosphorus in soils by extraction with sodium bicarbonate. Circular 939, March 1954 Washington DC, US Department of Agriculture. pp. 19.

12. Klute A (Ed.) 1986. Methods of Soil Analysis. Agron. Series 9. Am. Soc. Agron. Publ. Madison. WI, USA. pp. 1173.

13. Schlichting E, HP Blume and K Stahr 1995. Bodenkundliches Praktikum No. 81. Blackwell Wissenschafts-Verlag, Berlin. pp. 295.

14. Jackson M L 1973. Soil Chemical Analysis. Prentice-Hall, Inc., Englewood Cliff, NJ. pp. 498.

15. Cresser MS and JW Parsons 1979. Sulphuric-perchloric acid digestion of plant material for the determination of nitrogen, phosphorus, potassium, calcium and magnesium. Anal. Chim. Acta 109: 431-436.

16. Sys Ir C, E Ranst Van, Ir J Devabeye and F Beernaert. 1993. Land Evaluation: Part III Crop Requirements. pp. 86-88.

17. BARC 2018. Fertilizer recommendation guide 2018. Bangladesh Agricultural Research Council, Farmgate, Dhaka 1215. p. 223

18. Ahsan E and Z Karim 1988. Soil and management research on upland soils of Bangladesh. In: Proceedings of the International Conference on the Management and Fertilization of Upland Soils in the Tropics and Subtropics. pp. 247-251.

19. Chatta HR ASGA, Hafiz IA, Ahmad S and Khan M 2002. Nitrogen concentration at various growth stages of mango and effect of calcium carbide on fruit quality. Asian J. Plant Sci. 1(2): 164-166. 
20. Zeng $\mathrm{Q}$, Brown $\mathrm{PH}$ and BA Holtz 2001. Potassium fertilization affects soil $\mathrm{K}$, leaf $\mathrm{K}$ concentration and nutrient yield and quality of mature pistachio trees. Hort. Sci. 36(1): 85-89.

21. QDAF 2015. Queensland Department of Agriculture and Fisheries. Food for Fruit - Nutrition Management in Mangoes (Part I), Australia.

(Manuscript received on 5 September, 2019; revised on 5 October, 2019) 